\title{
Reproductive characteristics of Siahmahi, Capoeta damascina (Family: Cyprinidae) in Beheshtabad River, Tigris basin
}

\author{
Masoud Siami, Yazdan Keivany* and Omidvar Farhadian \\ Department of Natural Resources (Fisheries Division), Isfahan University of Technology, Isfahan \\ 84156-83111, Iran \\ *Corresponding author: keivany@cc.iut.ac.ir
}

\begin{abstract}
A total of 426 specimens of Mesopotamian barb (Siahmahi) Capoeta damascina (Cyprinidae) were caught by gillnets (1-6 cm mesh sizes) from Beheshtabad River, Chaharmahal and Bakhtiari Province from May 2013 to June 2014. Fish specimens were anesthetized in $1 \%$ clove oil solution, fixed in $10 \%$ buffered formalin and transported to the laboratory for further analyses. Fork lengths of the sampled fish ranged from $8.94 \mathrm{~cm}$ to $42.45(23.32 \pm 6.53 \mathrm{SD}) \mathrm{cm}$ and total weight from 10.3 to $1255.5(242.5 \pm 213.4) \mathrm{g}$. Based on scale readings, the maximum age was found to be $7^{+}$years for males and $8^{+}$ for females. Six reproductive characteristics, viz: sex ratio, Gonadosomatic Index (GSI), Hepatosomatic Index (HSI), relative fecundity, absolute fecundity and ova diameter were determined. The smallest mature male and female were 11.2 and 18.5 $\mathrm{cm}$ in fork length respectively. Sex ratio was 1M:0.7F. The GSI showed that spawning occurred from March to June. Oocyte

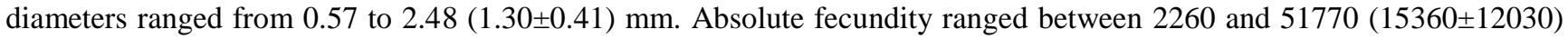
eggs. Absolute fecundity and fish size (fork length and total weight) were highly correlated. Relative fecundity varied from 11 to $65(33 \pm 12)$ eggs per gram of total body weight. The average hepatosomatic index was $2.25 \pm 0.05$ and the highest value was observed in March (3.05 \pm 0.31$)$.
\end{abstract}

Keywords: Capoeta damascina, Cyprinidae, Fecundity, Gonadosomatic index, Ova diameter, Sex ratio

\section{INTRODUCTION}

The cyprinid fish, Siahmahi or Mesopotamian barb, Capoeta damascina (Valenciennes, 1842), is a very abundant native fish in Iran (Keivany et al. 2016) and other countries in Middle East such as southern and eastern parts of Turkey, the eastern Mediterranean coast of Syria, Lebanon and coastal rivers of Palestine (Khalaf 1987; Krupp and Schneider 1989; Stoumboudi et al. 1993; Fishelson et al. 1996; Schöter et al. 2009). Like salmons, $C$. damascina is a strong counter-current swimmer, capable of jumping very strongly and rapidly (Fishelson et al. 1996). Although morphometrics, parasites, scale structure, age, growth and reproduction characteristics of the mesopotamian barb in the Middle East waters have been studied extensively (Khalaf 1987; Stoumboudi et al. 1993; Fishelson et al. 1996; Abdoli \& Mostafavi 2009; Soofiani \& Asadollah 2010; Asadollah et al. 2011; Jalali \& Miar 2011; Samaee \& Patzner 2011; Marammazi et al. 2014; Razavipour et al. 2015a, b; Asadollah et al. 2017), little is known on reproduction of this fish in Karun River basin such as
Beheshtabad River, where Mesopotamian barb is mainly caught for consumption.

The aim of this study was to determine reproductive characteristics of $C$. damascina including: sex ratio, length and age at first maturity, Gonadosomatic and Hepatosomatic Indices, ovum diameter, absolute fecundity and relative fecundity in Beheshtabad River, a tributary of Karun river in Tigris basin of Chaharmahal-va-Bakhtiari province, Iran, to provide the basic data for its management and conservation in this basin.

\section{MATERIAL AND METHODS}

Beheshtabad River is located approximately $40 \mathrm{~km}$ southwest of the city of Shahrekord $\left(32^{\circ} 01^{\prime} 50^{\prime \prime} \mathrm{N}\right.$; $\left.50^{\circ} 37^{\prime} 45^{\prime \prime} \mathrm{E}\right)$. Monthly samples were collected from May 2013 to June 2014 to determine some environmental factors including water temperature, $\mathrm{pH}$, conductivity (EC) and total dissolved solid (TDS) of water using a HANNA water quality measuring instrument (model HI 98129). 


\section{Siami et al.}

Specimens were caught by gillnets of $1-6 \mathrm{~cm}$ mesh sizes (30m long, $1.5 \mathrm{~m}$ depth). Fish samples were anesthetized with $1 \%$ clove oil, fixed in $10 \%$ buffered formalin and transported to the laboratory for further analyses. In the laboratory, fork length (FL) was measured to the nearest $0.1 \mathrm{~mm}$ and total weight and weight of gonads were measured to the nearest $0.01 \mathrm{~g}$. For the age determination, scales were taken from above the lateral line below the anterior part of the dorsal fin. Each scale was cleaned with $5 \% \mathrm{KOH}$. After preparing the scale, age reading was carried out through microscopic examination of annuli (Biswas 1993). To validate the ageing, each scale was read by three people and coincided readings were recorded.

The spawning period was determined by identifying monthly changes in the gonadosomatic (GSI) and hepatosomatic index (HSI). The GSI and HSI were calculated using the following equations (Biswas 1993; Nikolsky 1963).

GSI $=\frac{\text { Weight of gonad }}{\text { Total weight of fish }} \times 100$
HSI $=\frac{\text { Weight of liver }}{\text { Total weight of fish }} \times 100$

For the estimation of absolute and relative fecundities, the ovaries of ripe females at maturity stage III and above were used (Brown-Peterson et al. 2011). Ovaries were removed, weighed and then placed in Gilson's fluid for two days to harden eggs and dissolve ovarian membranes. Absolute fecundity (F) was estimated using the gravimetric method as follows (Wootton 1998):

$$
\mathrm{F}=\text { Gonad weight } \mathrm{x} \frac{\text { Egg number in the sub sample }}{\text { Sub sample weight }}
$$

The relative fecundity (Bagenal and Tesch 1978) was calculated as:

$$
\text { Relative fecundity }=\frac{\mathrm{F}}{\text { Total body weight }}
$$

Mean egg diameter was examined by measuring 30 eggs (10 oocytes from anterior, middle and posterior parts of each ovary). Measurements were made to the nearest $0.01 \mathrm{~mm}$ under a microscope with an ocular micrometer. Comparisons of GSI and HIS values during the year, ova diameter and fecundity in different ages were carried out by analysis of variance (ANOVA). Overall sex ratio was assessed using the Chi-square test incorporating Yate's correction for continuity (Sokal and Rholf 2012). All the comparisons were performed at $95 \%$ confidence level using SPSS 19 and Excel 2010 software.

\section{RESULTS}

\section{Physicochemical properties of the water}

The mean values \pm SD and range for water temperature, $\mathrm{pH}$, conductivity (EC) and total dissolved substances (TDS) are indicated in Table 1.

Table 1 Changes in some environmental factors of Beheshtabad River water during May 2013-June 2014.

\begin{tabular}{lll}
\hline Factor & Mean \pm SD & Range \\
\hline Water temperature $\left({ }^{\circ} \mathrm{C}\right)$ & $12.47 \pm 4.7$ & $3.2-19.7$ \\
pH & $8.6 \pm 0.37$ & $7.9-9.4$ \\
EC $\left(\mu \mathrm{s} \mathrm{cm}^{-1}\right)$ & $690.5 \pm 158.5$ & $504-982$ \\
TDS $\left(\mathrm{mg} \mathrm{L}^{-1}\right)$ & $343.3 \pm 81.95$ & $25-495$ \\
\hline
\end{tabular}

\section{Length frequency and sex ratio}

Amongst the 426 fish examined, 241(56\%) were male, $169(40 \%)$ female and $16(4 \%)$ undetermined. The fork length ranged from 8.94 to $42.95(23.32 \pm 6.53 \mathrm{SD}) \mathrm{cm}$ and weight ranged from 10.3-1255.5 (242.59 \pm 213.5$)$ $\mathrm{g}$. The majority of fishes were in the range of 19.10$23.00 \mathrm{~cm}$ for males and $23.10-27.00 \mathrm{~cm}$ for females (Table 2). The maximum age of the population based on scale reading was $7^{+}$years for males and $8^{+}$years for females. The overall sex ratio of males to females was 1M:0.7F and Chi-square analysis showed a significant difference from the 1:1 ratio $\left(\chi^{2}=12.295, \mathrm{P}<0.001\right)$.

The smallest mature males and females were in the 11.1-15 and 15.1-19 cm length classes, respectively (The smallest mature male was $11.19 \mathrm{~cm}$ and the smallest mature female was $18.50 \mathrm{~cm}$ in fork length) (Table 2). The mean age at first maturity of $C$. damascina for males was $\leq 2$ years (all specimens at age $2^{+}(100 \%)$ were mature), and the age at first maturity for females was $3^{+}$years. 
M. Siami et al.

Table 2 Stages of first sexual maturity of male and female $C$. damascina of different fork length groups

\begin{tabular}{|c|c|c|c|c|c|c|}
\hline \multirow{2}{*}{$\begin{array}{l}\text { Length class } \\
\text { (cm) }\end{array}$} & \multicolumn{3}{|c|}{ Male } & \multicolumn{3}{|c|}{ Female } \\
\hline & $\mathrm{n}$ & $\begin{array}{c}\text { Number of } \\
\text { mature }\end{array}$ & $\begin{array}{c}\% \\
\text { mature }\end{array}$ & $\mathrm{n}$ & $\begin{array}{c}\text { Number of } \\
\text { mature }\end{array}$ & $\begin{array}{c}\% \\
\text { mature }\end{array}$ \\
\hline $11-15$ & 4 & 4 & $100^{\mathrm{a}}$ & 6 & 0 & 0 \\
\hline $15-19$ & 66 & 66 & 100 & 9 & 1 & 11.1 \\
\hline $19-23$ & 105 & 105 & 100 & 37 & 19 & $51.4^{\mathrm{a}}$ \\
\hline $23-27$ & 33 & 33 & 100 & 41 & 40 & 97.6 \\
\hline $27-31$ & 19 & 19 & 100 & 29 & 29 & 100 \\
\hline $31-35$ & 13 & 13 & 100 & 24 & 24 & 100 \\
\hline $35-39$ & 1 & 1 & 100 & 13 & 13 & 100 \\
\hline $39-43$ & - & - & - & 10 & 10 & 100 \\
\hline
\end{tabular}

Gonadosomatic and hepatosomatic index

The average gonadosomatic index (GSI) of male and female fish was achieved as $3.92 \pm 0.23$ and $4.96 \pm 0.30$, respectively, which were significantly different $(\mathrm{p}<0.05)$. The highest GSI values were observed in March and May, for males and females, respectively. The average hepatosomatic index was $2.25 \pm 0.05$ and the highest HSI values were observed in March (3.05 \pm 0.31). The spawning season for $C$. damscina in Beheshtabad River, based on the GSI values, seasonal development of the ovary, direct observation of the gonads and also HSI values, was determined to commence in March (at $13.5-15.5^{\circ} \mathrm{C}$ ) and end in June (Figure 1).

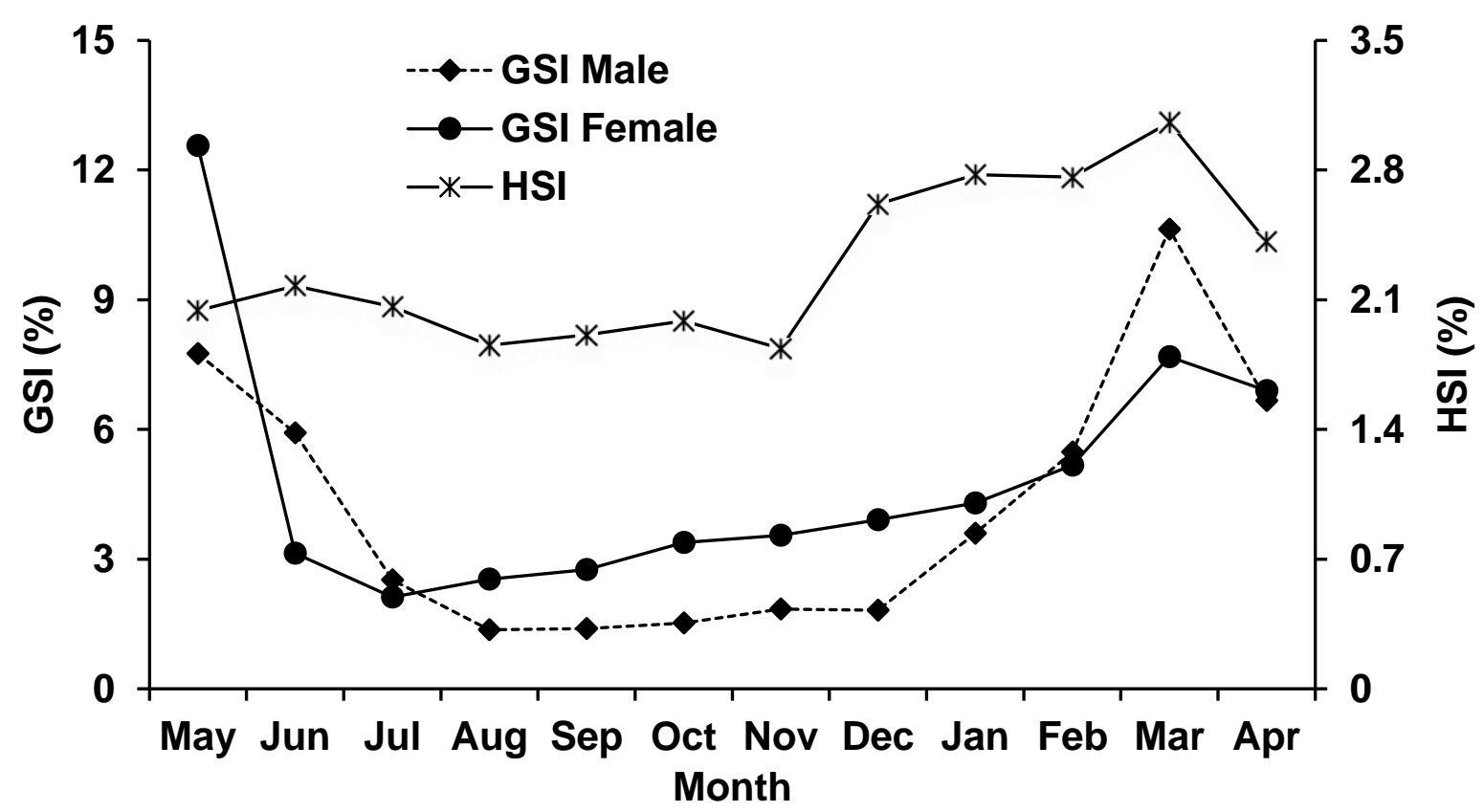

Fig. 1 Annual cycle of gonadosomatic (males, females) and hepatosomatic indices (both) for C. damascina in Beheshtabad River

Fecundity and oocyte diameters

Oocyte diameters ranged from 0.52 to $2.48 \mathrm{~mm}$, with a mean value of $1.3 \pm 0.41(\mathrm{SD})$. The mean egg diameter reached its maximum size in May as $2.05 \pm 0.12 \mathrm{~mm}$, while its minimum size was measured in July as $0.84 \pm$
$0.13 \mathrm{~mm}(\mathrm{P}<0.05)$. Two types of eggs were found in the ovary; smaller than $0.6 \mathrm{~mm}$ and larger than $0.6 \mathrm{~mm}$ (Table 3). 
Table 3 The monthly variations (mean \pm SD) of egg diameter of $C$. damascina in Beheshtabad River

\begin{tabular}{lccc}
\hline Month & $\begin{array}{c}\text { Mean fork length } \pm \\
\mathrm{SD}(\mathrm{cm})\end{array}$ & $\begin{array}{c}\text { Mean egg diameter } \\
\pm \mathrm{SD}(\mathrm{mm})\end{array}$ & Range \\
\hline May & $34.8 \pm 0.9$ & $2.05 \pm 0.23$ & $1.35-2.48$ \\
June & $30.1 \pm 4.4$ & $0.92 \pm 0.12$ & $0.55-1.15$ \\
July & $30.9 \pm 3.0$ & $0.84 \pm 0.16$ & $0.52-1.1$ \\
August & $31.9 \pm 3.2$ & $1.23 \pm 0.28$ & $0.7-1.7$ \\
September & $25.5 \pm 1.4$ & $1.10 \pm 0.1$ & $0.68-1.58$ \\
October & $36.7 \pm 4.6$ & $1.13 \pm 0.09$ & $0.75-1.55$ \\
November & $26.4 \pm 1.5$ & $1.20 \pm 0.18$ & $0.62-1.58$ \\
December & $28.2 \pm 5.3$ & $1.10 \pm 0.21$ & $0.58-1.55$ \\
January & $24.3 \pm 0.5$ & $1.19 \pm 0.19$ & $0.62-1.7$ \\
February & $30.3 \pm 3.4$ & $1.39 \pm .019$ & $0.75-2.05$ \\
March & $32.8 \pm 4.6$ & $1.43 \pm 0.27$ & $0.78-2.23$ \\
April & $37.8 \pm 4.1$ & $1.92 \pm 0.24$ & $1.28-2.45$ \\
\hline
\end{tabular}

Absolute and relative fecundity in different ages for $C$. damascina in Beheshtabad River is reported in Table 4. The relationship between body weight (BW)-absolute fecundity $(\mathrm{AF})\left(\mathrm{AF}=41.107 \mathrm{BW}-2468.8, \mathrm{R}^{2}=0.79\right)$ and age (T)-absolute fecundity $(\mathrm{AF}=7056.1 \mathrm{~T}-24988$, $\left.\mathrm{R}^{2}=0.62\right)$ were highly correlated.

Table 4 Absolute and relative fecundity in different age groups of $C$. damascina in Beheshtabad River

\begin{tabular}{cccccccc}
\hline \multirow{2}{*}{ Age } & $\mathrm{N}$ & $\begin{array}{c}\text { Body } \\
\text { weight }(\mathrm{g})\end{array}$ & $\begin{array}{c}\text { Fork length } \\
(\mathrm{cm})\end{array}$ & \multicolumn{2}{c}{$\begin{array}{c}\text { Absolute fecundity } \\
\text { (Number) }\end{array}$} & \multicolumn{2}{c}{$\begin{array}{c}\text { Relative fecundity } \\
\text { (Number /g of body weight) }\end{array}$} \\
\cline { 2 - 7 } & & Mean $\pm \mathrm{SD}$ & Mean $\pm \mathrm{SD}$ & Mean \pm SD & Range & Mean \pm SD & Range \\
\hline $4^{+}$ & 9 & $213.5 \pm 55.9$ & $23.3 \pm 1.5$ & $6873.6 \pm 2393.4$ & $2266-10135$ & $32.5 \pm 10.6$ & $14.6-49.2$ \\
$5^{+}$ & 5 & $261.2 \pm 75.3$ & $25.6 \pm 2.8$ & $6184.6 \pm 1962.5$ & $3060-7993$ & $24.1 \pm 6.9$ & $14.1-31.6$ \\
$6^{+}$ & 7 & $487.7 \pm 178.6$ & $30.9 \pm 4.1$ & $14345.0 \pm 7411.3$ & $3887-24644$ & $29.6 \pm 12.9$ & $12.0-44.9$ \\
$7+$ & 8 & $518.7 \pm 126.7$ & $32.0 \pm 2.4$ & $20994.1 \pm 7726.9$ & $12718-36303$ & $41.2 \pm 13.4$ & $23.8-65.8$ \\
$8^{+}$ & 3 & $1030.3 \pm 220.1$ & $40.2 \pm 2.2$ & $43496.7 \pm 7689.4$ & $36574-51773$ & $43.1 \pm 8.7$ & $33.6-50.7$ \\
\hline Total & 32 & $433.8 \pm 265.2$ & $29.1 \pm 5.8$ & $15363.8 \pm 1224.1$ & $2266-51773$ & $33.7 \pm 12.4$ & $12.0-65.8$ \\
\hline
\end{tabular}

\section{DISCUSSION}

The sex ratio of Mesopotamian barb in Beheshtabad River was 1M:0.7F. Gharache (2008) in a Qanat of southern Isfahan and Stoumboudi et al. (1993) in Jordan River reported similar results. This ratio for $C$. damascina in other areas were in favour of females (Mazaheri 2007; Soofiani and Asadollah 2010; Asadollah et al. 2011). Differences in sex ratio might be related to the interspecific differences in adapted population of a species to different ecological conditions, different in the date and time of capture, fishing gear, location, different growth rates and different mortalities in males and females, migration of mature fishes from the region and different behavior pattern in male and female fish (Qasim 1966; Fishelson et al. 1996; Keivany and Soofiani 2004; Soofiani et al. 2006; Asadollah et al. 2011; Keivany et al. 2012; Abaszadeh et al. 2013; Tabatabaei et al. 2014; Keivany and Daneshvar 2015).

Age of first sexual maturity in this study was $<2^{+}$ for males and $3^{+}$years for females. Age at sexual maturity of $C$. damascina living in Iranian waters was reported as $2^{+}$and $4^{+}$for males and females (Soofiani and Asadollah 2010; Asadollah et al. 2011). In the present study, the smallest mature male and female fish were 11.5 and $18.5 \mathrm{~cm}$, respectively. Study of reproductive cycle of this species in three rivers in 
M. Siami et al.

Lebanon showed that males of $C$. damascina reach maturity at $18 \mathrm{~cm}$ and the females at $20 \mathrm{~cm}$ (Khalaf 1987). Stoumboudi et al. (1993) also found that males in Lake Tiberias mature between 16 and $25 \mathrm{~cm}$ and females between 20 and $25 \mathrm{~cm}$ total length. Soofiani and Asadollah (2010) and Asadollah et al. (2011) reported the size at first maturity as $13.5 \mathrm{~cm}$ for males and $24-25 \mathrm{~cm}$ for females. Females, generally, attained maturity at an older age than males and generally, many other cyprinids fish males reach maturity at smaller sizes than females.

The spawning of $C$. damascina occured in May to June. The gonadosomatic index reached the highest value in March (10.63) for males and in May (12.57) for females. The reproduction period of this species was in March-June (Figure 1). In previous studies, it was recorded as May (Asadollah et al. 2011), May-June (Soofiani and Asadollah 2010) and April-June (Gharache 2008; Mazaheri 2007) (Table 5). Khalaf (1987) recorded that in Lebanese rivers the spawning of this species began in May and ended in June. However, according to Stoumboudi et al. (1993), $C$. damascina in the Jordan River spawned between January and March, depositing its eggs among gravel and pebbles in small streams. Egg diameter value was the highest in May $(2.48 \mathrm{~mm})$ and the smallest $(0.84$ $\mathrm{mm}$ ) in July (Table 3). The highest ova diameter in Zayandehrud River (Asadollah et al. 2011) and
Lebanese rivers (Khalaf 1987) have been recorded as 2.28 and $2.00 \mathrm{~mm}$, a figure similar to that of the present study. The diameter of the ova depends on the size and species and individuals which belong to the same species may have ova of different sizes in different regions. The highest average HSI value was observed in March, coinciding with the highest value of GSI. Generally there is an inverse relationship between GSI and HSI; about a month before peaking the GSI, the HSI decreases due to consumption of the lipids for vitellogenesis, but in cases where feeding is continued during spawning, this trend is not observed (Wootton 1977; Abaszadeh et al. 2013). In C. damascina, the positive correlation between HIS and GSI may be due to the reason that feeding intensity remains unchanged during spawning.

In this study, the fecundity of $C$. damascina was found to vary between 2,266 and 51,773. The fecundity of $C$. damascina reported by other researchers (Gharache 2008; Khalaf 1987; Soofiani and Asadollah 2010; Asadollah et al. 2011) was between 2,073 and 72,645 eggs (Table 5). Differences in fecundity in these studies might be related to, amongst others, differences in sampling methods, frequency of spawning, egg size, population density and environmental factors (Nikolsky 1963; Bagenal 1978; Jonsson and Jonsson 1999).

Table 5 Comparison of fecundity and reproduction season in C. damascina in different regions AF - Absolute fecundity; RF - Relative fecundity

\begin{tabular}{|c|c|c|c|c|c|}
\hline Study area & $\begin{array}{l}\text { Sex } \\
\text { ratio } \\
(\mathrm{M}: \mathrm{F})\end{array}$ & $\begin{array}{l}(\mathrm{AF}) \mathrm{Mean} \pm \mathrm{SD} \\
(\min -\max )\end{array}$ & $\begin{array}{l}(\mathrm{RF}) \text { Mean } \pm \mathrm{SD} \\
(\min -\max )\end{array}$ & $\begin{array}{c}\text { Reproductive } \\
\text { period }\end{array}$ & References \\
\hline Lebanese rivers & - & 5138 & - & May-June & Khalaf (1987) \\
\hline Jordan River & $1: 0.6$ & - & - & $\begin{array}{l}\text { January - } \\
\text { March }\end{array}$ & $\begin{array}{l}\text { Stoumboudi et al } \\
\text { (1993) }\end{array}$ \\
\hline Zayandehrud River & $1: 2.8$ & - & - & April-May & Mazaheri (2007) \\
\hline Qanat of Isfahan & $1: 0.7$ & $\begin{array}{c}9715 \\
(1190-19620)\end{array}$ & $339(58-839)$ & April-May & Gharache (2008) \\
\hline $\begin{array}{l}\text { Daleki \& Shahpour } \\
\text { rivers }\end{array}$ & $1: 1.5$ & 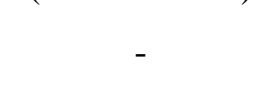 & - & - & $\begin{array}{c}\text { Abdoli and } \\
\text { Mostavi (2009) }\end{array}$ \\
\hline Hanna Wetland & $2.2: 1$ & $(2023-36763)$ & - & May-June & $\begin{array}{c}\text { Soofiani \& } \\
\text { Asadollah (2010) }\end{array}$ \\
\hline Zayandehrud River & $1: 1.6$ & $\begin{array}{c}24811 \\
(2523-72645)\end{array}$ & $28.7 \pm 11.4$ & May & $\begin{array}{c}\text { Asadollah et al. } \\
\text { (2011) }\end{array}$ \\
\hline Beheshtabad River & $1: 0.7$ & $\begin{array}{c}15363.84 \pm \\
1224.1(2266- \\
51773)\end{array}$ & $\begin{array}{l}33.73 \pm 12.43 \\
(11.96-65.82)\end{array}$ & May & Present Study \\
\hline
\end{tabular}




\section{Acknowledgments}

We would like to thank S. Asadollah, M. Aalipour and S. Mortazavi for their help in the collection of samples. This study was financially supported by Isfahan University of Technology.

\section{REFERENCES}

Abaszadeh A., Y. Keivany, N.M. Soofiani and A. Falahatimarvast 2013. Reproductive biology of the greater lizardfish, Saurida tumbil (Bloch, 1795), in Bushehr coastal waters of Iran. Turkish Journal of Zoology 37: 717-722. doi: 10.3906/zoo-1301-23

Abdoli A. and H. Mostafavi 2009. Preliminary investigation of some biological characteristics of Capoeta damascina in Daleki and Shahpour rivers, Boushehr Province, Southern Iran. Research Project, Institute of Environmental Sciences, Shahid Beheshty University, Tehran, $57 \mathrm{pp}$.

Asadollah S., N.M. Soofiani, Y. Keivany and M. Shadkhast 2011. Reproduction of Capoeta damascina (Valenciennes, 1842), a Cyprinid Fish, in Zayandeh-Roud River, Iran. Journal of Applied Ichthyology 27: 1061-1066. doi: 10.1111/j.1439-0426.2011.01758.x

Asadollah S., N.M. Soofiani, Y. Keivany and R. Hatami 2017. Age and Growth of the Mesopotamian Barb, Capoeta damascina, in Central Iran. Iranian Journal of Fisheries Sciences 15: In press.

Bagenal T.B. 1978. Aspects of Fish Fecundity. pp. 75101. In: S.D. Gerking (ed.), Ecology of Freshwater Fish Production. Wiley, New York. Bagenal T. and F. Tesch 1978. Age and growth. pp. 101-136. In: F. Bagenal (ed.), Methods for Assessment of Fish Production in Freshwaters. IBP Handbook 3, Blackwell Scientific Publications, Oxford.

Biswas S.P. 1993. Manual of Methods in Fish Biology. South Asian Publishers, New Delhi. 157 pp.

Brown-Peterson N.J., D.M. Wyanski, F. Saborido-Rey, B.J. Macewicz and S.K. Lowerre-Barbieri 2011. A standardized terminology for describing reproductive development in fishes. Marine and Coastal Fisheries 3(1): 52-70.

doi:http://dx.doi.org/10.1080/19425120.2011.5 55724
Fishelson L., M. Gren, J. Van Vuren and R. Manelis 1996. Some aspects of the reproduction biology of Barbus spp., Capoeta damascina and their hybrids (Cyprinidae, Teleostei) in Israel. Hydrobiologia 317: 79-88. doi:10.1007/BF00013728

Gharache M. 2008. On the biology of Capoeta damascina in qanat of southern Isfahan Province central Iran. BSc. Project. Gonbad Higher Education Center, Gonbad, Iran, 75 pp.

Jalali Jafari B. and A. Miar 2011. Metazoan parasite community of Capoeta damascina (Valenciennes in Cuvier and Valenciennes, 1842), Tigris Basin, Mesopotamian region- a checklist. Iranian Journal of Veterinary Research 12: 265-270.

Jonsson N. and B. Jonsson 1999. Trade-off between egg mass and egg number in brown trout. Journal of Fish Biology 55: 767-783. doi: 10.1111/j.1095-8649.1999.tb00716.x

Keivany Y. and E. Daneshvar 2015. Reproduction of an isolated Iranian cichlid, Iranocichla hormuzensis. Caspian Journal of Environmental Sciences 13(2): 119-128.

Keivany Y. and N.M. Soofiani 2004. Contribution to the biology of Zagros tooth-carp, Aphanius vladykovi, in central Iran (Cyprinodontidae). Environmental Biology of Fishes 71(2): 165169. doi:10.1007/s10641-004-0106-y

Keivany Y., M. Nasri, K. Abbasi and A. Abdoli 2016. Atlas of inland water fishes of Iran. Iran Department of Environment Press, Tehran. 218 pp.

Keivany Y., P. Zare and L. Kalteh 2012. Age, Growth and Reproduction of the Female Kutum, Rutilus kutum (Kamensky, 1901) (Teleostei: Cyprinidae), in Gorgan-Rud Estuary, Northern Iran. Research in Zoology 2: 7-14. doi: 10.5923/j.zoology.20120203.01

Khalaf G. 1987. Le cycle sexuel de Capoeta damascina (Cyprinidae) dans les cours d eau libanais. Cybium 11: 395-401.

Krupp F. and W. Schneider 1989. The fishes of the Jordan River drainage basin and Azraq Oasis. Fauna of Saudi Arabia 10: 347-416.

Marammazi M., M. Zakeri, M.T. Ronagh, P. Kochanian and M. Haghi 2014. Diet and feeding indices of small scale sardeh fish (Capoeta damascina) in Sezar River (Lorestan province). Journal of Animal Research 27(3): 405-416.

Sri Lanka J. Aquat. Sci. 22(1) (2017): 21-27 
M. Siami et al.

Mazaheri Z. 2007. Age and growth of Capoeta damascina in Zayande-Roud River Isfahan Province, Central Iran. BSc Project Isfahan University of Technology, Isfahan, Iran. 85 pp.

Nikolsky G.V. 1963. The ecology of fishes. Academic Press, London, $352 \mathrm{pp}$.

Qasim S.Z. 1966. Sex ratio in fish populations as a function of sexual differences and growth rate. Current Science 35: 140-142.

Razavipour P., S. Eagderi, H. Poorbagher and Y. Keivany. 2015a. Phenotypic plasticity of the Tuini fish, Capoeta damascina, (Actinopterygii: Cyprinidae) populations in Iranian part of Tigris basin using geometric morphometric approach. Journal of Animal Researches 28(2): 170-179.

Razavipour P., S. Eagderi, H. Poorbagher, A. Javanshir Khooi and Y. Keivany 2015b. Comparative study of morphological characteristics of Tuini fish (Capoeta damascina) in inland water of Iran using geometric morphometric method. Journal of Fisheries 68(1): 79-90.

Samaee S.M. and R.A. Patzner 2011. Morphometric differences among populations of Tuini, Capoeta damascina. (Teleostei: Cyprinidae), in the interior basins of Iran. Journal of Applied Ichthyology 27: 928-933. doi: 10.1111/j.14390426.2010.01587.x

Schöter C., Özuluğ, M. and J. Freyhof 2009. Capoeta caelestis, a new species from Göksu River, Turkey (Teleostei: Cyprinidae). Ichthyological Exploration of Freshwaters 20(3): 229-236.

Sokal R.R. and F.J. Rholf 2012. Biometry: The Principles and Practice of Statistics in Biological Research. Fourth Edition. W.H. Freeman, New York. 937 p.

Soofiani N.M., Y. Keivany and A.M. Shooshtari 2006. Contribution to the biology of the lizardfish, Saurida tumbil (Teleostei: Aulopiformes), from the Persian Gulf. Zoology in the Middle East 38: 49-56. doi:10.1080/09397140.2006.10638164

Soofiani M.N. and S. Asadollah 2010. Some aspects of the growth and reproduction of (Capoeta damascina valenciennes1842) from the Hanna wetland, Semirum. Iranian Scientific Fishery Journal 18: 145-156.

Stoumboudi M.T., W. Villwock, J. Sela and M. Abraham 1993. Gonadosomatic index in Barbus longiceps, Capoeta damascina and their hybrid (Pisces, Cyprinidae) versus spermatozoan index in the parental males. Journal of Fish Biology 43: 865-875. doi:10.1111/j.1095-8649.1993.tb01161.x

Tabatabaei S.N., I. Hashemzadeh-Segherloo, A. Abdoli, M. Milani and M. Mirzaei 2014. Age and growth of spirlins, Alburnoides eichwaldii and A. namaki, from the Caspian, Kavir and Namak basins of Iran. Iranian Journal of Ichthyology 1: 266-273.

Wootton R.J. 1977. Effect of food limitation during the breeding season on the size, body components and egg production of female sticklebacks (Gasterosteus aculeatus). The Journal of Animal Ecology 1977: 823-834. doi: 10.2307/3643

Wootton R.J. 1990. Ecology of Teleost Fishes. Chapman and Hall, London. 